\title{
In Praise of and a Critique of Nicholas Maxwell's In Praise of Natural Philosophy: A Revolution for Thought and Life
}

\author{
Robert K. Logan (iD) \\ Department of Physics, School of the Environment and St. Michael's College, University of Toronto, \\ Toronto, ON M5S 1A7, Canada; logan@physics.utoronto.ca
}

Received: 10 August 2018; Accepted: 20 August 2018; Published: 20 August 2018

"Where is the wisdom we have lost in knowledge?

Where is the knowledge we have lost in information?"-T.S. Eliot

Nicholas Maxwell [1] makes an excellent point in his book In Praise of Natural Philosophy: A Revolution for Thought and Life, which I am happy to support with some reservations. The separation of natural philosophy into the various disciplines of science and philosophy has provided both a service and a disservice.

The service is that specializing and narrowing the scope of study in the sciences has led to a better understanding of nature. It also has led to the extension of the methodology of science to the study of the social interactions of humans, known as the social sciences. The specialization of philosophy has led to a better understanding of the various disciplines of science and social science, as well many of the topics that natural philosophy has dealt with such as ethics and values.

The disservice of the separation of natural philosophy into science and philosophy and the narrowing of the scope of study involves the problems of specialization and the loss of context. "Philosophers are people who know less and less about more and more, until they know nothing about everything. Scientists are people who know more and more about less and less, until they know everything about nothing". This quote, ascribed to Konrad Lorenz, in a certain sense captures some of the concerns of Nicholas Maxwell.

There is another dimension to the concerns of Maxwell that stems from the way that science is practiced, namely, that science is value-free and objective for it to be universal and solely evidence-based. An historic example of why this is important is the objections that the Roman Catholic Church had to the Copernican heliocentric theory of the solar system, which in some way slowed the progress of the Scientific Revolution.

The Church had no objections to the practice of science up to the publication of Copernicus's revolutionary theory of helio-centricism. In fact, many of the earliest scientists were priests and churchmen, as the following lists indicates.

Robert Grosseteste (1175-1273), Bishop of Lincoln, England, who studied optics and geometry, introduced the idea of controlled experiments and suggested that the laws of physics pertained to both matter on Earth and in the heavens.

Roger Bacon (1219/20-1292), Franciscan Friar, father of the scientific method, mathematician and astronomer who researched optics, alchemy (discovered gun powder), and agronomy; he was also a reformer of the calendar that was the forerunner of the Gregorian calendar.

William of Ockham (1287-1347), an English Franciscan monk, was a logician, a physicist, and a theologian; he was most famous for his argument for logical simplicity (parsimony) known as Ockham's Razor. 
Jean Buridan (1295-1363) was a French priest who formulated the notion of impetus, which was the forerunner of inertia initially discovered by Galileo and incorporated into Newton's Laws of Motion as the First Law.

Albert of Saxony (1320-90), Bishop of Halberstadt, contributed to logic and physics.

Nicholas of Oresme (1320-82), Bishop of Lisieux, wrote on economics, mathematics, physics, astronomy, and theology. As a forerunner of Copernicus, he entertained the notion that the Earth was in motion about the Sun but concluded he did not have enough evidence to assert that that was the case.

Nicholas Copernicus (1473-1543) was a priest, one of four candidates for Bishop of Warmia; he studied for and earned a doctorate in Canon Law in Bologna. Copernicus sensed that his revolutionary theory of heliocentrism would be met with resistance by the Church and therefore did not consent to the publication of De revolutionibus orbium coelestium (On the Revolutions of the Heavenly Spheres) until the end of his life, receiving the printer's proofs of his book while he was on his death bed.

Copernicus's concerns were well founded, as the Church attempted to suppress the Copernican theory including the work of Galileo's as well. This is what I believe ultimately led to the division between science and philosophy, even though Newton still used the term natural philosophy but made it clear that his mechanics was strictly evidence-based.

Because of the unfortunate suppression of Copernican theory, scientists developed an aversion to anything that dealt with religion or values as being out of bounds for science. The only value embraced by science was its demand that all science be evidence-based. Maxwell has critiqued this central value of science by suggesting that there is no evidence that evidence-based science leads to truth.

Physics makes a persistent, substantial metaphysical (i.e. untestable) assumption about the nature of the universe: it is such that, at the very least, no seriously disunified, non-explanatory theory is true. The universe is (more or less) physically comprehensible (i.e., such that physical explanations for phenomena exist to be discovered). Thus, physics does make a persistent assumption about the universe independent of evidence-even, in a certain sense, in violation of evidence-and that means standard empiricism is false.

In his attempt to rescue natural philosophy, Maxwell suggests that the basic principle, which led to so much understanding of our universe, is not valid. This is where Maxwell's criticism goes too far for me. The evidence that evidence-based science is appropriate is that it has led to a better understanding of the world in which we live and has led directly to developments that have improved the well-being of humankind. This is my critique of Maxwell.

My praise for Maxwell is that he underscores what is missing in science, namely, its inability, given its modus operandum, to deal with values and the impacts of science and science-based technology. Here, Maxwell strikes a responsive chord with me. Additionally, this is where the integration or partnership of science with philosophy that Maxwell calls for makes a lot of sense and earns my praise. I would suggest, however, that rather than going back to what was natural philosophy, we need to move forward and explore new ways of integrating science and philosophy.

Philosophy literally means the love of wisdom, and perhaps this is the missing ingredient in both sciences and philosophies. As the term science is derived from the Latin term scientia, meaning knowledge, what Maxwell is calling for is an integration of knowledge with wisdom. In my work in the field of knowledge management, I came up with the following relationship of data, information, knowledge, and wisdom:

- Data are the pure and simple facts without any particular structure or organization, the basic atoms of information,

- Information is structured data, which adds meaning to the data and gives it context and significance,

- Knowledge is the ability to use information strategically to achieve one's objectives, and 
- Wisdom is the capacity to choose objectives, so they are consistent with one's values and within a larger social context [2].

To integrate the knowledge of the scientists with the love of wisdom of the philosophers will not be any easy task. The only way to achieve such an integration is to organize dialogues of scientists and philosophers. This is something that I have been organizing at the University of Toronto at St. Michael's College and the School of the Environment, both of which I am cross-appointed to. The dialogues between theologians and environmental scientists have focused on discussing global warming and climate change in the context of Pope Francis's encyclical Laudato si'. Lest the reader thinks that this activity was strictly organized from the perspective of Roman Catholicism, I will mention that I am a Jewish physicist concerned with the impending disaster that will surely be the result of climate change. It is too late to avert this crisis with a sustainability strategy. The only hope to minimize the damage will be with a resiliency strategy. This will require the integration of the knowledge of science with the wisdom that only philosophy or philosophical thinking is capable of producing. If this can be achieved, not only will we minimize the damage that climate change will create, but it will also be a step in the direction of resurrecting the natural philosophy that Maxwell is calling for.

Conflicts of Interest: The authors declare no conflict of interest.

\section{References}

1. Maxwell, N. In praise of natural philosophy a revolution for thought and life. Philosophia 2012, 40, 705-715. [CrossRef]

2. Logan, R.K.; Stokes, L.W. Collaborate to Compete: Driving Profitability in the Knowledge Economy; Wiley: New York, NY, USA, 2004; ISBN 7-5080-3669-7. 